\title{
The intangible index in bank management
}

\author{
Ma del Consuelo Ruiz-RodrígueziD, Francisca Castilla-Polo iD \\ Universidad de Jaén (Spain) \\ moruiz@ujaen.es,fpolo@ujaen.es
}

Received September, 2018

Accepted December, 2019

\begin{abstract}
Purpose: Our research objective is to perform a descriptive analysis of the information on intangible assets disclosed by Spanish banks indexed on the IBEX 35 as a step prior to the creation of which allows us to eventually create a specific disclosure index for this type of content during 2010-2012, the most critical years of the crisis in Spain.
\end{abstract}

Design/methodology: In a first section of the methodology, it has been carried out a content analysis using five categories that cover all the terms that were considered the most relevant in the literature on intangible assets: concepts of intellectual capital, human capital, structural capital, relational capital and usefulness of information. This information has been the basis for the design of an index by categories and global as a second part of the methodological design.

Findings: Our results found that the disclosure level of Spanish financial entities in terms of intangibles is reduced with an aggregate index of intangible assets of 0.2698 (between 0 and 1). Although, within the categories proposed it can be highlighted the priority role of the usefulness information index followed by the relational and human capital indexes.

Research limitations/implications: The study focuses on 2010 to 2012, which conditions and justifies the results obtained for a period of crisis such as the one analyzed.

Practical implications: Our results confirm that the financial entities have not bet for the use of the disclosure of information on intangibles during the crisis despite their potential value in order to guarantee a competitive business performance.

Social implications: Managers of financial institutions may have a comparative vision of the disclosure of intangibles and adopt future disclosure policies that consider the value of this information.

Originality/value: As the main contribution, this paper incorporates the results of a specific index on intangibles (both globally and specifically for 5 categories) for financial institutions. Our resultsopen future lines of research that analyze why not use this information for competitive purposes and, specifically, to gain confidence in a context as difficult as that experienced in the years of crisis studied.

Keywords: Intangible assets, Voluntary disclosure, Banks, Content analysis, Index, Human capital, Relational capital, Structural capital, Usefulness and information

Jel Codes: G21, C43 


\section{To cite this article:}

Ruíz-Rodríguez, M.C., \& Castilla-Polo, F. (2019). The intangible index in bank management. Intangible Capital, 15(3), 171-189. https://doi.org/10.3926/ic.1366

\section{Introduction}

Banks are a type of organization were voluntary disclosures is a relatively unknown practice, despite persistent social demand for transparency due to the unease that arises after an economic crisis (Kohlbeck, 2004; Bravo, Abad \& Trombetta, 2009; Abdifatah \& Mubaraq, 2012; Chen, Danbolt \& Holland, 2014; Ferreira, Ribeiro, Gomes-Rodrígues \& Muñoz, 2017). They are considered responsible, to high degree, for the recession and, for this reason, additional information is required to explain their behaviour not only on an economic level but also from an ethical point of view. Following Ferreira et al. (2017), the financial turbulence in this sector is a key issue to managing information, transparency, and reliability as a way to obtain trust and security.

In this context, this paper was focused on information voluntarily disclosed by these financial institutions to respond to the social information demands made by society. Specifically, we define our efforts on intangible assets, elements considered by literature to be strategic keys to success and company competitiveness. In fact, according to the Global Intangible Financial Tracker report (GIFT) (Brand Finance, 2017), the growth of the global value of intangible assets has reached a percentage of $47 \%$ of the total value of these organizations. This figure added to the reduced presence of these assets within the statutory accounts to explain the use of the voluntary disclosures as a form of accountability (Cañibano, García-Meca, García-Osma \& Gisbert, 2009; TracyAnne, Stratford \& Clark, 2014).

The disclosure of intangible assets is used in the banking sector by interest groups to exceed legal requirements and to provide additional data on the structure and composition of the intangible estate (Bamber \& McMeeking, 2010). Chen and Pan (2011) also suggest that its management, due to its complexity, requires greater transparency and reliability to protect its interest groups, where both financial and non-financial account information plays a key role (Kohlbeck, 2004; Lopes, 2010; Shakina \& Molodchik, 2014). The GIFT (2017) report even pointed to the Spanish banking sector for holding first place in the sector with regard to the volume of hidden intangible assets. This explains why the disclosure policies of our banks must be analysed and managed in an effective manner, this being an information gap that we intend to cover.

Some recent analysis of disclosure of intangible assets in financial institutions can be found in the following papers. Ferreira et al. (2017) analysed the Portuguese bank's policies regarding the disclosure of intangible assets in annual reports and corporate websites, and concluded that the former hold more information of this kind. Munthopa (2013) studied the scope of the voluntary disclosure of intellectual capital of commercial banks in Malawi. Rodríguez, Fuentes and Sánchez (2013) created a client, community, employees, and environment information indexes as well as other comprehensive information during the period of 2007-2010 in Spain. Haji and Mubaraq (2012) analyzed the disclosure of intellectual capital within Nigerian banks during the period of 2006-2009. Also Herrera and Macagnan (2016) focused on the banking sector by creating an index of these assets, albeit for a time period prior to the one we set out to review, 2006-2011, in Spain and Brazil, as well as Panama in another similar work (Herrera \& Macagnan, 2012).

Our research objective consists on conducting a descriptive analysis on intangible information disclosed by Spanish banks listed on the IBEX 35, that allows us to eventually create a disclosure index specific to this kind of content by aggregating the gross results summary (Holsti, 1969), more easily understood and globally comparable. This study contributes to the research in voluntary disclosures of intangible assets in financial institutions for two reasons. In first place and unlike the observations focused on the annual report, our study revises all known sources of primary information, which expands the range of documents and avoids all weaknesses resulting from using this report exclusively as a source of "non-financial" information (Castilla \& Ruiz, 2017). Secondly, we must indicate that incorporating the period 2010-2012 of full economic crisis justifies 
the "non-financial" disclosure policy that are of special interest for these years when analysing accountability. Previous papers have analysed the target population group, but for periods that were less turbulent than the years studied, in which the crisis was in full swing and demands for transparency by financial institutions were continuous and persistent.

Regarding the methodology, this study has analyzed the intangible assets disclosure policies during 2010-2012 by 5 categories: concepts of intellectual property, human capital, structural capital, relational capital and information usefulness, at the same time, aggregating these to the global index of the disclosure of intangible assets that outline the disclosure policy of these entities in a single value. In this way, we can reach conclusions on the trends observed and create a long-term corporate vision (Vandemaele, Vergauwen \& Smith, 2005; Blaise, Carson \& Phillips, 2008; Abdifatah \& Mubaraq, 2012; De Silva, Stratford \& Clark, 2014; Tracy-Anne et al., 2014).

The results have allowed us to quantify the aggregated index for the studied period at $26.98 \%$, a level that has remained constant through the studied years, supporting the idea that a there is a constant intangible asset disclosure strategy. On the other hand, it must be stated that stability has continued at different calculated partial rates. There are significant differences in their value that ranges from values close to $20 \%$ for two of these partial indexes -intellectual capital and structural capital index- to values above that of $40 \%$ for the index that is mostly present in the intangible asset policy of these banks, the information usefulness index. The latter has been incorporated as a novelty in this paper.

Finally, we must indicate that the structure of our work is as follows: we will immediately focus on reviewing the use of indexes in the field of the disclosure of intangible information. In the third section, we focus on outlining how our research has been based on a methodological point of view, the kind of index chosen and the primary explanations and comments regarding its calculation. In the fourth section, we outline the calculation of partial indexes and the aggregated index, which is the final goal of this research. In the final section, we will review the most relevant conclusions, the limitations observed and future actions that could be carried out in this line of research.

\section{Literature review: The intangibles indexes}

The use of indexes for intangible disclosures has captured the attention of academics for years. It includes both specific studies regarding the requirement of the mandatory information on these assets, fundamentally the NIIF 38 Standard Intangible Assets (IASB, 2004) (Teodori \& Veneziani, 2010; Ragini, 2012; Devalle, Rizzato \& Busso, 2016), as well as those within a wider vision of all those intangible assets that escape recognition in the accounting books. "Though the construction of an index, the level of intangible disclosure and the concern of companies regarding these elements can be outlined" (Teodori \& Veneziani, 2010, pp. 4). Continuing the important line of work that has already been started by classical authors such as Williams (2001) and, more recently, by authors such as Ferreira et al. (2017), in Table1 it has been incorporated the most relevant aspects of this topic.

\begin{tabular}{|l|l|l|l|l|}
\hline Author/Year & $\begin{array}{l}\text { Population under } \\
\text { study }\end{array}$ & $\begin{array}{l}\text { Type of index } \\
\text { created / Type of } \\
\text { variables used }\end{array}$ & $\begin{array}{l}\text { Research } \\
\text { objectives }\end{array}$ & Main results \\
\hline $\begin{array}{l}\text { Ferreira et al. } \\
\mathbf{( 2 0 1 7 )}\end{array}$ & $\begin{array}{l}\text { 28 banks in Portugal } \\
\text { and 25 banking } \\
\text { administrators }\end{array}$ & $\begin{array}{l}\text { Unweighted banking } \\
\text { sector disclosure index }\end{array}$ & $\begin{array}{l}\text { Construction of an } \\
\text { intellectual capital } \\
\text { index. Differentiate } \\
\text { between the annual } \\
\text { reports and } \\
\text { corporate web } \\
\text { intangible assets } \\
\text { disclosures. }\end{array}$ & $\begin{array}{l}\text { The scale of intellectual capital } \\
\text { disclosures is greater in the } \\
\text { annual reports that the } \\
\text { corporate websites of the Banks } \\
\text { and the most disclosed } \\
\text { categories are human and } \\
\text { structural capital. Relational } \\
\text { capital is the most disclosed } \\
\text { category on websites. }\end{array}$ \\
\hline
\end{tabular}




\begin{tabular}{|c|c|c|c|c|}
\hline Author/Year & $\begin{array}{l}\text { Population under } \\
\text { study }\end{array}$ & $\begin{array}{l}\text { Type of index } \\
\text { created / Type of } \\
\text { variables used }\end{array}$ & $\begin{array}{l}\text { Research } \\
\text { objectives }\end{array}$ & Main results \\
\hline $\begin{array}{l}\text { Lim, White, } \\
\text { Lee and } \\
\text { Yuningsih } \\
\text { (2017) }\end{array}$ & $\begin{array}{l}28 \text { biotechnological } \\
\text { Australian companies } \\
\text { quoted in 2003, } 2006 \\
\text { and } 2010\end{array}$ & $\begin{array}{l}\text { Weighted disclosure } \\
\text { index for the internal } \\
\text { capital, external capital, } \\
\text { and human capital } \\
\text { No dummy variable }\end{array}$ & $\begin{array}{l}\text { Measurement the } \\
\text { quality of the } \\
\text { disclosure of } \\
\text { voluntary } \\
\text { information of } \\
\text { intellectual } \\
\text { information. }\end{array}$ & $\begin{array}{l}\text { The quality of the voluntary } \\
\text { disclosure of internal and } \\
\text { external capital diminishes over } \\
\text { time, using as a basis of } \\
\text { comparison the first year of } \\
\text { study, 2003. The disclosure of } \\
\text { lesser quality was of human } \\
\text { capital, and that of greater } \\
\text { quality was of internal capital. }\end{array}$ \\
\hline $\begin{array}{l}\text { Sharma and } \\
\text { Kaur (2016) }\end{array}$ & $\begin{array}{l}11 \text { Indian companies } \\
\text { for the period } \\
\text { between 2012-2013 }\end{array}$ & $\begin{array}{l}\text { Unweighted banking } \\
\text { sector disclosure index } \\
\text { for internal and external } \\
\text { capital and that of } \\
\text { employee competition. } \\
\text { Dummy variable }\end{array}$ & $\begin{array}{l}\text { Examine the scope } \\
\text { of the disclosure of } \\
\text { intangible assets in } \\
\text { annual reports and } \\
\text { on websites } \\
\text { according to } \\
\text { category, element, } \\
\text { sector, and size. }\end{array}$ & $\begin{array}{l}\text { The intangible asset reports are } \\
\text { reduced and narrated. The } \\
\text { category with the highest level } \\
\text { of disclosure was internal } \\
\text { capital, followed by external } \\
\text { capital and the employee } \\
\text { competitions. }\end{array}$ \\
\hline Tejedo (2016) & $\begin{array}{l}23 \text { companies trading } \\
\text { on the IBEX35 for } \\
\text { the period of } 2004- \\
2008\end{array}$ & $\begin{array}{l}\text { Unweighted banking } \\
\text { sector disclosure of } \\
\text { intangible assets. } \\
\text { Dummy variable }\end{array}$ & $\begin{array}{l}\text { Explore the quantity } \\
\text { of disclosed } \\
\text { intangible } \\
\text { information. }\end{array}$ & $\begin{array}{l}\text { The most disclosed intangible } \\
\text { assets are the philosophy of } \\
\text { management of the company } \\
\text { and corporative culture. It has } \\
\text { been detected that the } \\
\text { enterprises disclose more data } \\
\text { on their intellectual capital } \\
\text { within the sustainability reports }\end{array}$ \\
\hline $\begin{array}{l}\text { Herrera and } \\
\text { Macagnan } \\
(2016)\end{array}$ & $\begin{array}{l}29 \text { banks in Brazil } \\
\text { and in Spain for the } \\
\text { period between } \\
2006-2011\end{array}$ & $\begin{array}{l}\text { Unweighted banking } \\
\text { sector disclosure of } \\
\text { structural organizational } \\
\text { capital. } \\
\text { Dummy variable }\end{array}$ & $\begin{array}{l}\text { Analyze the } \\
\text { characteristics that } \\
\text { motivate } \\
\text { representatives of } \\
\text { structural } \\
\text { organizational } \\
\text { capital to voluntarily } \\
\text { disclose intangible } \\
\text { information. }\end{array}$ & $\begin{array}{l}\text { The large, older and more } \\
\text { profitable Banks voluntarily } \\
\text { disclose more information } \\
\text { about their structural } \\
\text { organizational capital. }\end{array}$ \\
\hline $\begin{array}{l}\text { Gorgan and } \\
\text { Gorgan (2014) }\end{array}$ & $\begin{array}{l}14 \text { companies trading } \\
\text { in the Bucharest } \\
\text { stock market }\end{array}$ & $\begin{array}{l}\text { Unweighted disclosure } \\
\text { index on the level of } \\
\text { disclosure of intangible } \\
\text { assets in general. } \\
\text { Dummy variable }\end{array}$ & $\begin{array}{l}\text { Analyze the level of } \\
\text { disclosure of } \\
\text { companies in } \\
\text { compliance with the } \\
\text { requirements of the } \\
\text { IAS } 38 \text { regulation. }\end{array}$ & $\begin{array}{l}\text { A significant level of non- } \\
\text { compliance with NIC } 38 \text { was } \\
\text { revealed. It has been observed a } \\
\text { positive moderated association } \\
\text { between the scale of disclosure } \\
\text { according to the requirements } \\
\text { of NIC } 38 \text { and the reputation of } \\
\text { the auditor. }\end{array}$ \\
\hline Tejedo (2014) & $\begin{array}{l}23 \text { companies trading } \\
\text { in IBEX35 in } 2008\end{array}$ & $\begin{array}{l}\text { Unweighted disclosure } \\
\text { index for structural, } \\
\text { relational, and human } \\
\text { capital. } \\
\text { Dummy variable }\end{array}$ & $\begin{array}{l}\text { Describe the } \\
\text { evolution between } \\
\text { the quantity and } \\
\text { quality of voluntary } \\
\text { information } \\
\text { disclosed on } \\
\text { intellectual capital. }\end{array}$ & $\begin{array}{l}\text { The category where the most } \\
\text { information was disclosed was } \\
\text { relational capital and human } \\
\text { capital, highlighting a } \\
\text { predominance of disclosure of } \\
\text { items related to the profile of } \\
\text { employees and has not } \\
\text { undergone significant change } \\
\text { during the period studied. }\end{array}$ \\
\hline
\end{tabular}




\begin{tabular}{|c|c|c|c|c|}
\hline Author/Year & $\begin{array}{l}\text { Population under } \\
\text { study }\end{array}$ & $\begin{array}{l}\text { Type of index } \\
\text { created / Type of } \\
\text { variables used }\end{array}$ & $\begin{array}{l}\text { Research } \\
\text { objectives }\end{array}$ & Main results \\
\hline $\begin{array}{l}\text { Bellora and } \\
\text { Guenther } \\
(2013)\end{array}$ & $\begin{array}{l}51 \text { European } \\
\text { companies }\end{array}$ & $\begin{array}{l}\text { Unweighted disclosure } \\
\text { index for innovation } \\
\text { capital. } \\
\text { No dummy variable }\end{array}$ & $\begin{array}{l}\text { Examine the } \\
\text { characteristics of the } \\
\text { disclosure of } \\
\text { innovation capital } \\
\text { and analyze the } \\
\text { relationship between } \\
\text { this and the industry, } \\
\text { location, and } \\
\text { implemented } \\
\text { disclosure policies. }\end{array}$ & $\begin{array}{l}\text { An average of } 29.12 \text { items of } \\
\text { innovation capital for } \\
\text { intellectual and industry capital, } \\
\text { the size of the company, } \\
\text { location, and implemented } \\
\text { disclosure policies that drive the } \\
\text { amount of information } \\
\text { disclosed was revealed. }\end{array}$ \\
\hline Kumar (2013) & $\begin{array}{l}74 \text { Asian companies } \\
\text { quoted in the US in } \\
2007 .\end{array}$ & $\begin{array}{l}\text { Unweighted disclosure } \\
\text { index: quantity and the } \\
\text { manner in which data is } \\
\text { revealed. } \\
\text { No dummy variable }\end{array}$ & $\begin{array}{l}\text { Analyze the role of } \\
\text { certain structural } \\
\text { variables in the } \\
\text { disclosure of } \\
\text { intangible assets. }\end{array}$ & $\begin{array}{l}\text { It was found that large } \\
\text { companies with property } \\
\text { dispersion and a low level of } \\
\text { debt were the ones that } \\
\text { disclosed the most of this kind } \\
\text { of information. }\end{array}$ \\
\hline $\begin{array}{l}\text { Rodríguez et } \\
\text { al. (2013) }\end{array}$ & $\begin{array}{l}336 \text { financial entities } \\
\text { of credit and deposit } \\
\text { in Spain from 2007- } \\
2010\end{array}$ & $\begin{array}{l}\text { Unweighted disclosure } \\
\text { index of responsibility } \\
\text { of clients, community, } \\
\text { employees, and } \\
\text { environment. } \\
\text { No dummy variable }\end{array}$ & $\begin{array}{l}\text { Analyze the } \\
\text { disclosure of social } \\
\text { and environmental } \\
\text { information of } \\
\text { Spanish financial } \\
\text { institutions. }\end{array}$ & $\begin{array}{l}\text { The heterogeneity of the } \\
\text { disclosed information stands } \\
\text { out. Social institutions disclosed } \\
\text { information about clients and } \\
\text { community while, in general, } \\
\text { the most disclosed categories } \\
\text { are community and } \\
\text { environmental. }\end{array}$ \\
\hline $\begin{array}{l}\text { Munthopa } \\
\text { (2013) }\end{array}$ & $\begin{array}{l}5 \text { commercial Banks } \\
\text { quoted and not } \\
\text { quoted in Malawi in } \\
2011\end{array}$ & $\begin{array}{l}\text { Unweighted disclosure } \\
\text { index for internal, } \\
\text { external and human } \\
\text { capital. } \\
\text { Dummy variable }\end{array}$ & $\begin{array}{l}\text { Analyze the reach of } \\
\text { disclosure of } \\
\text { voluntary } \\
\text { information on } \\
\text { intellectual capital } \\
\text { within the annual } \\
\text { reports of the } \\
\text { commercial banks in } \\
\text { Malawi. }\end{array}$ & $\begin{array}{l}80 \% \text { of the banks analyzed } \\
\text { disclosed intellectual capital } \\
\text { from the three analyzed } \\
\text { categories, the disclosure of } \\
\text { internal capital standing out, } \\
\text { followed by external capital and, } \\
\text { in last place, human capital. }\end{array}$ \\
\hline $\begin{array}{l}\text { Haji and } \\
\text { Mubaraq (2012) }\end{array}$ & $\begin{array}{l}20 \text { Nigerian banks } \\
\text { during 2006-2009 }\end{array}$ & $\begin{array}{l}\text { Unweighted disclosure } \\
\text { index for internal, } \\
\text { external and human } \\
\text { capital. } \\
\text { Dummy variable }\end{array}$ & $\begin{array}{l}\text { Longitudinally } \\
\text { examine the } \\
\text { intellectual capital } \\
\text { disclosures of } \\
\text { Nigerian banks after } \\
\text { the restructuring of } \\
\text { the banking sector. }\end{array}$ & $\begin{array}{l}\text { The disclosure of intellectual } \\
\text { capital moderately increased } \\
\text { during the study period. The } \\
\text { category that was most } \\
\text { disclosed was human capital. }\end{array}$ \\
\hline $\begin{array}{l}\text { Herrera and } \\
\text { Macagnan } \\
(2012)\end{array}$ & $\begin{array}{l}39 \text { banks quoted on } \\
\text { the capital markets in } \\
\text { Panama, Brazil, and } \\
\text { Spain during 2006- } \\
2011\end{array}$ & $\begin{array}{l}\text { Unweighted disclosure } \\
\text { index of human, } \\
\text { technological structure, } \\
\text { organizational structure } \\
\text { capitals and social and } \\
\text { business relational } \\
\text { capital. } \\
\text { Dummy variable }\end{array}$ & $\begin{array}{l}\text { Analyze the level of } \\
\text { transparency } \\
\text { between intangible } \\
\text { information in the } \\
\text { annual reports } \\
\text { published on } \\
\text { corporate websites. }\end{array}$ & $\begin{array}{l}\text { A significant difference between } \\
\text { the level of publication of } \\
\text { annual reports on the websites } \\
\text { of companies quoted in Panama } \\
\text { compared to that of Spain and } \\
\text { a little more to those quoted in } \\
\text { Brazil. }\end{array}$ \\
\hline Ragini (2012) & $\begin{array}{l}100 \text { Indian } \\
\text { companies, } 60 \\
\text { Japanese companies, } \\
\text { and } 100 \text { US } \\
\text { companies that } \\
\text { included in Fortune } \\
\text { Global } 500\end{array}$ & $\begin{array}{l}\text { Unweighted disclosure } \\
\text { index on intangible } \\
\text { corporate disclosures. } \\
\text { Dummy variable }\end{array}$ & $\begin{array}{l}\text { Analyze the quantity } \\
\text { of information of } \\
\text { disclosed intangible } \\
\text { assets and find } \\
\text { differences between } \\
\text { according to } \\
\text { country. }\end{array}$ & $\begin{array}{l}\text { An increase of disclosure of } \\
\text { intangible assets was revealed, } \\
\text { especially in the case of } \\
\text { Japanese companies. The } \\
\text { Intellectual Property Rights, } \\
\text { kindness and other intangible } \\
\text { assets, displayed a high increase } \\
\text { in five studied years by the } \\
\text { enterprises in the analyzed } \\
\text { countries. }\end{array}$ \\
\hline
\end{tabular}




\begin{tabular}{|c|c|c|c|c|}
\hline Author/Year & $\begin{array}{l}\text { Population under } \\
\text { study }\end{array}$ & $\begin{array}{l}\text { Type of index } \\
\text { created / Type of } \\
\text { variables used }\end{array}$ & $\begin{array}{l}\text { Research } \\
\text { objectives }\end{array}$ & Main results \\
\hline $\begin{array}{l}\text { Chander and } \\
\text { Mehra (2011) }\end{array}$ & $\begin{array}{l}243 \text { companies of } \\
\text { BT-500 ranking in } \\
\text { Indian }\end{array}$ & $\begin{array}{l}\text { Weighted disclosure of: } \\
\text { human, external, } \\
\text { internal capital, notes of } \\
\text { intangible assets and } \\
\text { mandatory disclosure } \\
\text { requirements. } \\
\text { No dummy variable }\end{array}$ & $\begin{array}{l}\text { Analyze the level of } \\
\text { disclosure of } \\
\text { intangible assets. }\end{array}$ & $\begin{array}{l}\text { A greater amount of disclosure } \\
\text { is discovered for external capital } \\
\text { category. The information on } \\
\text { intangible assets is not } \\
\text { organized and is not systematic. }\end{array}$ \\
\hline $\begin{array}{l}\text { Kang and Gray } \\
\text { (2011) }\end{array}$ & $\begin{array}{l}\text { Top } 200 \text { entities } \\
\text { quoted in emerging } \\
\text { countries in } 2002\end{array}$ & $\begin{array}{l}\text { Unweighted disclosure } \\
\text { index on global } \\
\text { intangible assets. } \\
\text { Dummy variable }\end{array}$ & $\begin{array}{l}\text { Analyze the content } \\
\text { and relationship of } \\
\text { variables that can be } \\
\text { explained. }\end{array}$ & $\begin{array}{l}\text { They find that companies that } \\
\text { are actively committed to } \\
\text { disclosing their intangible assets } \\
\text { and are key variables when } \\
\text { explaining the implementation } \\
\text { of these practices: } \\
\text { IFRS/GAAP, kind of industry } \\
\text { and the book/market-value } \\
\text { ratio. }\end{array}$ \\
\hline $\begin{array}{l}\text { Oliveira, } \\
\text { Rodríguez- } \\
\text { Lima and } \\
\text { Craig(2010) }\end{array}$ & $\begin{array}{l}42 \text { reports on } \\
\text { sustainability } \\
\text { published by } \\
\text { Portuguese company } \\
\text { in the BCSD } \\
\text { website. }\end{array}$ & $\begin{array}{l}\text { Weighted disclosure } \\
\text { index on intangible } \\
\text { assets: strategy, } \\
\text { processes, technology, } \\
\text { innovation, research and } \\
\text { development, clients and } \\
\text { human capital. } \\
\text { No dummy variable }\end{array}$ & $\begin{array}{l}\text { Study the voluntary } \\
\text { disclosures of } \\
\text { information about } \\
\text { intellectual capital in } \\
\text { the sustainability } \\
\text { reports of } \\
\text { Portuguese } \\
\text { companies. }\end{array}$ & $\begin{array}{l}\text { The disclosure of intellectual } \\
\text { capital information is found } \\
\text { within corporate sustainability } \\
\text { reports that show a higher } \\
\text { application scale of the Global } \\
\text { Reporting initiative. }\end{array}$ \\
\hline $\begin{array}{l}\text { Rodríguez, } \\
\text { Gallego and } \\
\text { García (2010) }\end{array}$ & $\begin{array}{l}117 \text { companies } \\
\text { quoted on the } \\
\text { Madrid Stock } \\
\text { Exchange. }\end{array}$ & $\begin{array}{l}\text { Unweighted disclosure } \\
\text { index on clients, } \\
\text { community, employees } \\
\text { and environment. } \\
\text { Dummy variable }\end{array}$ & $\begin{array}{l}\text { Analyze the online } \\
\text { strategic information } \\
\text { disclosure policies } \\
\text { and determine } \\
\text { explanatory factors. }\end{array}$ & $\begin{array}{l}\text { The sectorial concentration in } \\
\text { the disclosure of strategic } \\
\text { information on the Internet is } \\
\text { contrasted with a potential } \\
\text { secondary effect of the use of } \\
\text { this information to reduce the } \\
\text { political costs incurred by } \\
\text { companies. }\end{array}$ \\
\hline $\begin{array}{l}\text { Teodori and } \\
\text { Veneziani } \\
(2010)\end{array}$ & $\begin{array}{l}\text { Companies quoted } \\
\text { in: S\&P Mib (40); } \\
\text { Star (54) and } \\
\text { TechStar (22) from } \\
\text { 2005-2006. }\end{array}$ & $\begin{array}{l}\text { Unweighted disclosure } \\
\text { index on intangible } \\
\text { assets according to IFRS } \\
38 . \\
\text { Dummy variable }\end{array}$ & $\begin{array}{l}\text { Analyze the } \\
\text { disclosure of } \\
\text { intangible assets as } \\
\text { well as the } \\
\text { differences between } \\
\text { these according to } \\
\text { whether they belong } \\
\text { to a specific quote } \\
\text { index. }\end{array}$ & $\begin{array}{l}\text { No significant differences exist } \\
\text { between the disclosure } \\
\text { according to index type and the } \\
\text { level was found to be low. }\end{array}$ \\
\hline $\begin{array}{l}\text { Bravo et al. } \\
(2009)\end{array}$ & $\begin{array}{l}35 \text { companies quoted } \\
\text { on IBEX 2000-2004 }\end{array}$ & $\begin{array}{l}\text { Quantity, dimension and } \\
\text { quality index. }\end{array}$ & $\begin{array}{l}\text { Analyze whether the } \\
\text { type of index affects } \\
\text { the amount of } \\
\text { information } \\
\text { disclosed. }\end{array}$ & $\begin{array}{l}\text { The impact the index type on } \\
\text { the analysis of the disclosed } \\
\text { information is no trivial matter. } \\
\text { The role of quantity in the } \\
\text { proxy of the quality of the } \\
\text { disclosed information. }\end{array}$ \\
\hline $\begin{array}{l}\text { Li, Pike and } \\
\text { Haniffa (2008) }\end{array}$ & $\begin{array}{l}100 \text { UK companies } \\
\text { in } 2004\end{array}$ & $\begin{array}{l}\text { Unweighted disclosure } \\
\text { index of human, } \\
\text { structural and relational } \\
\text { capital. } \\
\text { Dummy variable }\end{array}$ & $\begin{array}{l}\text { Study the power of } \\
\text { information about } \\
\text { corporate } \\
\text { governance on the } \\
\text { disclosed data of } \\
\text { intellectual capital. }\end{array}$ & $\begin{array}{l}\text { A significant difference between } \\
\text { intangible disclosure and all the } \\
\text { elements of corporate } \\
\text { governance, with the exception } \\
\text { of the duality of the functions } \\
\text { of the Chairman, was found. }\end{array}$ \\
\hline
\end{tabular}




\begin{tabular}{|c|c|c|c|c|}
\hline Author/Year & $\begin{array}{l}\text { Population under } \\
\text { study }\end{array}$ & $\begin{array}{l}\text { Type of index } \\
\text { created / Type of } \\
\text { variables used }\end{array}$ & $\begin{array}{l}\text { Research } \\
\text { objectives }\end{array}$ & Main results \\
\hline $\begin{array}{l}\text { Cerbioni and } \\
\text { Parbonetti } \\
(2007)\end{array}$ & $\begin{array}{l}54 \text { biotechnological } \\
\text { companies during } \\
2002-2004\end{array}$ & $\begin{array}{l}\text { Unweighted disclosure } \\
\text { index on internal } \\
\text { structure, external } \\
\text { structure and human } \\
\text { capital. } \\
\text { Dummy variable }\end{array}$ & $\begin{array}{l}\text { Examine the } \\
\text { connection between } \\
\text { various corporate } \\
\text { governance factors } \\
\text { and the scale of } \\
\text { disclosure of } \\
\text { information about } \\
\text { intellectual capital. }\end{array}$ & $\begin{array}{l}\text { The largest portion of } \\
\text { disclosure referred to internal } \\
\text { structure, followed by external } \\
\text { structure and, lastly, human } \\
\text { capital. } \\
\text { The structure of the board, } \\
\text { property and size were } \\
\text { associated in a negative way } \\
\text { with the level of disclosure of } \\
\text { information while the number } \\
\text { of independent councillors had } \\
\text { a positive effect. }\end{array}$ \\
\hline $\begin{array}{l}\text { Macagnan } \\
(2007)\end{array}$ & $\begin{array}{l}94 \text { companies that } \\
\text { trade on the Spanish } \\
\text { Stock Market for } \\
\text { objective one. }\end{array}$ & $\begin{array}{l}\text { Unweighted disclosure } \\
\text { index on human, } \\
\text { technological structure, } \\
\text { organizational structure, } \\
\text { business relational and } \\
\text { social relational } \\
\text { capitals. } \\
\text { Dummy variable }\end{array}$ & $\begin{array}{l}\text { Identify the } \\
\text { conditional factors } \\
\text { that explain the } \\
\text { extent of the } \\
\text { disclosure of } \\
\text { intangible assets. }\end{array}$ & $\begin{array}{l}\text { The greater the floating capital, } \\
\text { profitability and extent of } \\
\text { monopoly, the less the extent of } \\
\text { disclosure of intangible assets } \\
\text { of companies that trade on the } \\
\text { Spanish Stock Exchange. }\end{array}$ \\
\hline Kang (2006) & $\begin{array}{l}200 \text { companies in } \\
\text { emerging markets } \\
\text { found in Business } \\
\text { Week the 14th of } \\
\text { July, } 2003\end{array}$ & $\begin{array}{l}\text { Weighted disclosure } \\
\text { based on the Value } \\
\text { Chain Scoreboard. } \\
\text { Dummy variable }\end{array}$ & $\begin{array}{l}\text { Analyze the } \\
\text { associated factors } \\
\text { with voluntary } \\
\text { intangible disclosure } \\
\text { polices. }\end{array}$ & $\begin{array}{l}\text { General factors, such as } \\
\text { leverage, implementation of } \\
\text { unweighted disclosure index on } \\
\text { of IFRS, the type of industry, } \\
\text { the Price to book ratio and } \\
\text { specific dangers related to the } \\
\text { economic policies and judicial } \\
\text { methods are strongly related to } \\
\text { the scale of disclosure of } \\
\text { intangible assets. }\end{array}$ \\
\hline $\begin{array}{l}\text { Oliveira, } \\
\text { Rodríguez- } \\
\text { Lima and Craig } \\
(2006)\end{array}$ & $\begin{array}{l}56 \text { companies quoted } \\
\text { in Euronext Lisbon } \\
\text { in } 2003\end{array}$ & $\begin{array}{l}\text { Weighted disclosure } \\
\text { index for structural, } \\
\text { relational, and human } \\
\text { capital. } \\
\text { No dummy variable }\end{array}$ & $\begin{array}{l}\text { Identify the } \\
\text { structural factors } \\
\text { that affect the } \\
\text { disclosure of } \\
\text { intangible assets in } \\
\text { annual reports. }\end{array}$ & $\begin{array}{l}\text { The disclosure of intangibles is } \\
\text { conditioned by the size, } \\
\text { ownership concentration, kind } \\
\text { of auditor, industry and } \\
\text { whether during listing an } \\
\text { univariable analysis is made. } \\
\text { This disclosure of data about } \\
\text { intangible assets is influenced by } \\
\text { variables of size, sector, kind of } \\
\text { auditor and ownership } \\
\text { concentration. }\end{array}$ \\
\hline $\begin{array}{l}\text { Bergamini and } \\
\text { Zambon (2005) }\end{array}$ & $\begin{array}{l}16 \text { companies in the } \\
\text { Milan Stock Market } \\
\text { 1995-2000 and } 34 \\
\text { companies in New } \\
\text { Market in 2000: } 15 \\
\text { pharmaceutical } \\
\text { companies and } 15 \\
\text { telecommunication } \\
\text { companies. }\end{array}$ & $\begin{array}{l}\text { Weighted disclosure } \\
\text { index for intangible } \\
\text { assets. } \\
\text { No dummy variable }\end{array}$ & $\begin{array}{l}\text { Empirically prove } \\
\text { that the model } \\
\text { developed by } \\
\text { Ferrara University in } \\
\text { collaboration with } \\
\text { the Italian } \\
\text { Association of } \\
\text { Financial Analysts to } \\
\text { measure the level of } \\
\text { intangible assets } \\
\text { disclosed by Italian } \\
\text { companies. }\end{array}$ & $\begin{array}{l}\text { Companies quoted in the Milan } \\
\text { Stock Market disclose on } \\
\text { average more information on } \\
\text { intangible assets than New } \\
\text { Market companies do. The } \\
\text { information on intangible assets } \\
\text { seems to have increased in the } \\
\text { last five years except for } \\
\text { innovation and intellectual } \\
\text { property information that } \\
\text { remains constant. } \\
\text { The international companies } \\
\text { studied provide more } \\
\text { information on intangible assets } \\
\text { than Italian companies do. }\end{array}$ \\
\hline
\end{tabular}




\begin{tabular}{|c|c|c|c|c|}
\hline Author/Year & $\begin{array}{l}\text { Population under } \\
\text { study }\end{array}$ & $\begin{array}{l}\text { Type of index } \\
\text { created / Type of } \\
\text { variables used }\end{array}$ & $\begin{array}{l}\text { Research } \\
\text { objectives }\end{array}$ & Main results \\
\hline $\begin{array}{l}\text { Bukh, Nielsen, } \\
\text { Gormsen and } \\
\text { Mouritsen } \\
(\mathbf{2 0 0 5 )}\end{array}$ & $\begin{array}{l}68 \text { analyst reports of } \\
\text { Danish companies. }\end{array}$ & $\begin{array}{l}\text { General unweighted } \\
\text { disclosure index of } \\
\text { employees, information } \\
\text { technologies, processes, } \\
\text { I+D, clients, and } \\
\text { strategies. } \\
\text { Dummy variable }\end{array}$ & $\begin{array}{l}\text { Examine } \\
\text { information on } \\
\text { intangible assets in } \\
\text { Initial Public Offers } \\
\text { (IPO's) }\end{array}$ & $\begin{array}{l}\text { There has been a growth in the } \\
\text { disclosure of information in the } \\
\text { study period, above all for } \\
\text { employees of the firms, } \\
\text { strategies and R\&D }\end{array}$ \\
\hline $\begin{array}{l}\text { Fier and } \\
\text { Williams (2005) }\end{array}$ & $\begin{array}{l}390 \text { companies in } \\
\text { Singapore listed on } \\
\text { the stock market. }\end{array}$ & $\begin{array}{l}\text { Unweighted disclosure } \\
\text { index of intellectual } \\
\text { capital for human } \\
\text { resources, clients, } \\
\text { information } \\
\text { technologies, processes } \\
\text { and intellectual } \\
\text { property. } \\
\text { Dummy variable }\end{array}$ & $\begin{array}{l}\text { Determine the } \\
\text { association between } \\
\text { the ownership } \\
\text { structure and the } \\
\text { disclosure of } \\
\text { intellectual property. }\end{array}$ & $\begin{array}{l}\text { Companies owned by executive } \\
\text { councils are less likely to } \\
\text { disclose this kind of } \\
\text { information while companies } \\
\text { largely owned by government } \\
\text { disclose less information than } \\
\text { those that have a lower } \\
\text { percentage of government } \\
\text { ownership. }\end{array}$ \\
\hline $\begin{array}{l}\text { García-Meca, } \\
\text { Parra, Larrán } \\
\text { and Martínez } \\
(2005)\end{array}$ & $\begin{array}{l}231 \text { companies } \\
\text { during 2000-2001 }\end{array}$ & $\begin{array}{l}\text { Unweighted disclosure } \\
\text { index of human capital, } \\
\text { clients, processes, } \\
\text { research, development } \\
\text { and innovation, and } \\
\text { strategies. } \\
\text { Dummy variable }\end{array}$ & $\begin{array}{l}\text { Analyze the level of } \\
\text { information on } \\
\text { intellectual capital in } \\
\text { the analyst reports } \\
\text { and the } \\
\text { determination } \\
\text { factors. }\end{array}$ & $\begin{array}{l}\text { Little information on } \\
\text { intellectual capital was found in } \\
\text { the analyst's reports, with a } \\
\text { percentage reduction between } \\
2000 \text { and } 2001 \text {. The disclosure } \\
\text { was associated with the size of } \\
\text { the company. }\end{array}$ \\
\hline $\begin{array}{l}\text { Bozzolan, } \\
\text { Favotto and } \\
\text { Ricceri (2003) }\end{array}$ & $\begin{array}{l}30 \text { non-financial } \\
\text { organisations that } \\
\text { trade on the Italian } \\
\text { Stock Market. }\end{array}$ & $\begin{array}{l}\text { Unweighted index for } \\
\text { the total quantity of } \\
\text { disclosure and for each } \\
\text { category (internal } \\
\text { structure, external } \\
\text { structure, and human } \\
\text { capital) } \\
\text { Dummy variable }\end{array}$ & $\begin{array}{l}\text { Analyze the amount } \\
\text { and matter of } \\
\text { voluntary disclosure } \\
\text { of data about } \\
\text { intellectual capital } \\
\text { and study what } \\
\text { elements most } \\
\text { influence the } \\
\text { behaviour of the } \\
\text { different voluntary } \\
\text { reports. }\end{array}$ & $\begin{array}{l}\text { The most disclosed category } \\
\text { was external structure, } \\
\text { highlighting the number of } \\
\text { mentions of items, such as } \\
\text { customer support, distribution } \\
\text { channels, corporate and brand } \\
\text { collaboration. } \\
\text { The industry and size of these } \\
\text { are usually the elements that } \\
\text { best explain the difference in } \\
\text { conduct regarding voluntary } \\
\text { disclosure for Italian companies. }\end{array}$ \\
\hline $\begin{array}{l}\text { Beaulieu, } \\
\text { Williams and } \\
\text { Wright (2002) }\end{array}$ & $\begin{array}{l}30 \text { listed Swiss } \\
\text { companies }\end{array}$ & $\begin{array}{l}\text { Unweighted disclosure } \\
\text { index of human } \\
\text { resources, clients, } \\
\text { information } \\
\text { technologies and } \\
\text { processes, and } \\
\text { intellectual property. }\end{array}$ & $\begin{array}{l}\text { Study the practices } \\
\text { on intellectual } \\
\text { capital and } \\
\text { determining } \\
\text { factors. }\end{array}$ & $\begin{array}{l}\text { The most disclosed category } \\
\text { was human capital, followed by } \\
\text { clients, information } \\
\text { technologies, processes and } \\
\text { intellectual property. }\end{array}$ \\
\hline Gandía (2002) & $\begin{array}{l}100 \text { companies } \\
\text { found in the } \\
\text { Standard \& Poor's } \\
\text { Global100 index }\end{array}$ & $\begin{array}{l}\text { Weighted index under } \\
\text { three segments: content } \\
\text { indicators, navigability } \\
\text { indicators, and } \\
\text { accessibility-design } \\
\text { indicators. } \\
\text { No dummy variable }\end{array}$ & $\begin{array}{l}\text { Determine the } \\
\text { international scope } \\
\text { of the use of the } \\
\text { internet to reveal } \\
\text { information on } \\
\text { intangible assets or } \\
\text { intellectual capital. }\end{array}$ & $\begin{array}{l}\text { The level of disclosure was } \\
\text { categorized as insufficient and } \\
\text { there are significant differences } \\
\text { between the analyzed } \\
\text { companies and the quality of } \\
\text { the disclosed information of } \\
\text { their intangible assets. The } \\
\text { absence of content and the } \\
\text { deficient structure of their } \\
\text { websites reduces their } \\
\text { usefulness. }\end{array}$ \\
\hline
\end{tabular}




\begin{tabular}{|l|l|l|l|l|}
\hline Author/Year & $\begin{array}{l}\text { Population under } \\
\text { study }\end{array}$ & $\begin{array}{l}\text { Type of index } \\
\text { created / Type of } \\
\text { variables used }\end{array}$ & $\begin{array}{l}\text { Research } \\
\text { objectives }\end{array}$ & Main results \\
\hline Williams (2001) & $\begin{array}{l}\text { 31 companies sin the } \\
\text { UK belonging to the } \\
\text { FTSE 100 }\end{array}$ & $\begin{array}{l}\text { Unweighted disclosure } \\
\text { index of human } \\
\text { recourses, clients, } \\
\text { informatics } \\
\text { technologies, processes, } \\
\text { and intellectual property. } \\
\text { Dummy variable }\end{array}$ & $\begin{array}{l}\text { Study the disclosure } \\
\text { of data about } \\
\text { intellectual capital. }\end{array}$ & $\begin{array}{l}\text { The amount of data on } \\
\text { intellectual capital has increased } \\
\text { considerably in the studied } \\
\text { period. The connection between } \\
\text { performance and the disclosure } \\
\text { is not systematic although it is } \\
\text { prompted that if performance } \\
\text { is high, the amount of } \\
\text { disclosure can be reduced. }\end{array}$ \\
\hline
\end{tabular}

Table 1.Previous studies on intangible assets indexes

As can be deduced from Table 1, the research objectives of these studies mostly intended to quantify the disclosure of intangible assets through the creation of a global index regarding intellectual capital, as well as specific groups of this capital. In addition, it can be observed the use of the classical tripartite intellectual capital division centered on the study of human, structural and relational capital (Cerbioni \& Parbonetti, 2007; Haji \& Mubaraq, 2012; or Munthopa, 2013; among others). Other categories added by previous papers are the followings: innovation capital (Bellora \& Guenther, 2013); organizational structure capital (Herrera \& Macagnan, 2016); social capital (Herrera \& Macagnan, 2012); more exhaustive lists such as Oliveira et al. (2010): strategy, processes, technology, innovation, I+D, clients and human resources. All of them share the same concern about the analysis of quantity, leading us to conclude that, with some exceptions, are betting for quantity of intangible disclosures in detriment of their quality (García-Meca \& Martínez, 2005; Tejedo, 2011; Lim et al., 2017).

A common practice also involves constructing an index for a period of two to five years in order to observe the evolution and establish longitudinally conclusions. In general, the conclusions are positive (Bergamini \& Zambon, 2005; Ragini, 2012; Herrera \& Macagnan, 2016; and Tejedo, 2016; among others), except for some exceptional cases where a reduction of these practices is observed, as in the case of García-Meca et al. (2005).

At the same time, to compare between countries, transversally, is the specific goal in the following studies. Bergamini and Zambon (2005) corroborated that international companies in their study provided more information on intangible assets than Italian companies do. Kang and Gray (2011) study the role of legitimation of when explaining practices in emergent economies. Ragini (2012) compares India, Japan and USA, and concludes his analysis on how Japan excels in these matters. Companies that trade in the US are analysed by the Kumar (2013) study. Their results showed that the greatest disclosures of intangible assets were made by more individualistic countries. Finally, Herrera and Macagnan (2016) concluded that financial entities in Spain were the companies that disclosed the most information, followed by Panama and, in last place, Brazil.

It is also noted that there is a double objective when an intangible index is created. Along the assessment of these disclosures, it is common to associate them with different structural variables, for example size (GarcíaMeca et al., 2005; Oliveira et al., 2006; Cerbioni \& Parbonetti, 2007; Bellora \& Guenther, 2013; Herrera \& Macagnan, 2016; Sharma \& Kaur, 2016; among others), profitability (Williams, 2001; Macagnan, 2007; among others), level of indebtedness (Kumar 2013), ownership dispersion (Bergamini \& Zambon, 2005; Oliveira et al., 2006; and Kumar, 2013; among others) when listed in a certain index (Teodori \& Veneziani, 2010) or the subject of corporate governance at its different levels (Li et al., 2008; Cerbioni \& Parboneti, 2007; among others).

Finally, it is common to use unweighted indexes against weighted indexes. In all case studies, with the exception of the studies of Gandía (2002), Bergamini and Zambon (2005), Kang (2006) and Oliveira et al. (2006, 2010), an unweighted index is used on the items that form the study. This election is justified, among other reasons, for the subjectivity that weighted indexes add to the study. However, the authors of the previously mentioned studies argue that the presence or absence of the item is not enough, requiring the quantification of how this item is offered. In general, the weighted indexes have scales that go from 0 to 2 , quantifying the absence or presence according to the detail provided. 


\section{Methodological research design}

\subsection{Content analysis}

Content analysis has been the methodology used as a basis to analyze voluntary disclosure of intangible information of banks listed on the IBEX 35.

Regarding the target study population, it is made up of banks trading on the IBEX 35 stock market, for various reasons. In first place, we considered the small number of studies on Spanish companies, despite the fact that these areground-breaking with regard to the disclosure of intangible assets. Examples such as BBVA, Banco Santander, Bankinter and Popular Bank Group have a key role as leaders in the earliest moments of this kind of "non-financial" disclosure (Castilla \& Ruiz, 2014). In second place, because of the distrust issues the public has had with the banking sector and the role that voluntary disclosure, specifically regarding intangible assets, can have to regain trust. Intangible equity, not recognized in general terms within the basic financial information of any company, allows for the justification of the company's actions and any investments made to that effect (Zeghal \& Maaloul, 2011; and Dumay, 2013; among others). Finally, the specificity of these elements justifies any approach to specific industries, as in our case.

The chosen study period is three years, from 2010 to 2012 (inclusive). The reform of the Spanish Financial System and the consequent crisis lead us to consider that since 2010 there could be significant results in the area of voluntary disclosure and an analysis of this three-year period could be used to draw conclusions on the evolution or trend of this practice. During these years, as Ruiz and Castilla (2016) reviewed, a series of accountable measures were proposed to increase liquidity and clean up balance sheets (Royal-Decree Law 2/2011, RoyalDecree Law 2/2012, Royal-Decree Law 18/2012, Royal-Decree Law 24/2012), and at the same time, by extension, foster the credibility of and trust in interest groups. Therefore, we understood that this period could be crucial for these companies to increase voluntary disclosure by seeking to reach these goals.

Regarding sources of information, we must indicate that it was collected from the corporate websites of the selected banks. We also must highlight the importance of Law 26/2003 of the 17th of July, which intends to strengthen the transparency of public limited companies through measures such as an updated website with a minimum of content. A special note should be made on the reports that were used for the analysis of the bank's intangible disclosures. As one of the key contributions made by previous papers, we must indicate that our paper has increased the number of analysed sources in the content analysis made. It is obvious that not all banks disclose the same kind of reports, nor is the same amount of information found in the reports, due to their respective policies regarding voluntary disclosure that determines their size and focus. Even so, these are considered primary sources to avoid partial views focused exclusively in annual reports.

The model used to create our codification system was based on the Intellectus Model (IADE-CIC, 2003), which is described as a model to handle knowledge and strategic direction, increase the efficiency and effectiveness of organizations and create design methodologies, as well as distribute such information. This scheme offers disaggregated information though an exhaustive list of elements, indicators and variables that have allowed us to define the units of the associated records for each category and is detailed in Table 2.

\begin{tabular}{|l|l|c|l|}
\hline Categories & Registration Units & $\begin{array}{l}\text { Number of } \\
\text { registration units }\end{array}$ & Foundations \\
\hline $\begin{array}{l}\text { Intellectual } \\
\text { Capital } \\
\text { Concept }\end{array}$ & $\begin{array}{l}\text { Intangible assets, assets generated internally, intellectual capital, } \\
\text { differences between book value and market value, research, } \\
\text { development, administrative concessions, intellectual property, } \\
\text { goodwill, transfer rights, software tools, advances on intangible } \\
\text { assets. }\end{array}$ & $\begin{array}{l}\text { Set of accounting } \\
\text { terms related with } \\
\text { the recognition of } \\
\text { intangible assets }\end{array}$ \\
\hline $\begin{array}{l}\text { Human } \\
\text { Capital }\end{array}$ & $\begin{array}{l}\text { Employees, know-how, knowledge, education, training, } \\
\text { entrepreneurial spirit, equity, health and safety of employees, } \\
\text { professional certifications, professional development, business } \\
\text { studies, gender, impairments, employee relationship, well-being of } \\
\text { employees, seniority, age, number of employees, professional } \\
\text { experience, leadership of managers, apprenticeship and teamwork. }\end{array}$ & 25 & $\begin{array}{l}\text { Set of terms } \\
\text { associated with the } \\
\text { human assets of an } \\
\text { organization. }\end{array}$ \\
\hline
\end{tabular}




\begin{tabular}{|c|c|c|c|}
\hline Categories & Registration Units & $\begin{array}{l}\text { Number of } \\
\text { registration units }\end{array}$ & Foundations \\
\hline $\begin{array}{l}\text { Structural } \\
\text { Capital }\end{array}$ & $\begin{array}{l}\text { Intellectual property, technological and management processes, } \\
\text { corporate culture, information and network systems, research, } \\
\text { development and innovation, management philosophy, quality, } \\
\text { recognition, achievements, commercial brands, copyright, } \\
\text { infrastructure, organizational routines, strategies, procedure } \\
\text { manuals, data bases, process capital, product or service capital, } \\
\text { innovation or development capital, procedures, strategic reflexive } \\
\text { processes, technological processes, product technology, } \\
\text { information technology, organizational flexibility, organizational } \\
\text { capital, technological capital, perspective, patents, and ability to } \\
\text { improve. }\end{array}$ & 32 & $\begin{array}{l}\text { Set of terms } \\
\text { associated with the } \\
\text { internal structure of } \\
\text { the company. }\end{array}$ \\
\hline $\begin{array}{l}\text { Relational } \\
\text { Capital }\end{array}$ & $\begin{array}{l}\text { Financial relationships, brands, clients, corporate image, } \\
\text { distribution channels, license agreements, franchise agreements, } \\
\text { loyalty, client satisfaction, agreements with providers, abilities for } \\
\text { negotiation, strategic alliances, brand awareness. }\end{array}$ & 14 & $\begin{array}{l}\text { Set of words } \\
\text { associated with the } \\
\text { external } \\
\text { relationships of an } \\
\text { organization. }\end{array}$ \\
\hline $\begin{array}{l}\text { Information } \\
\text { usefulness }\end{array}$ & $\begin{array}{l}\text { Voluntary disclosure, management, corporative information, } \\
\text { management, shareholders, information needs, profitability, } \\
\text { satisfaction, user needs, value creation, performance, comparability, } \\
\text { relevance, trustworthiness, accurate picture, opportunity. }\end{array}$ & 18 & $\begin{array}{l}\text { Set of terms that } \\
\text { study the value of } \\
\text { the companies' } \\
\text { intangible } \\
\text { information. }\end{array}$ \\
\hline
\end{tabular}

Table 2. Scheme of used categories and units

With the previously selected categories, the codification started with the ATLAS.tiprogram. The presence or absence of the concepts previously described was counted using the following rules: tables, graphics, boxes, and diagrams were coded but not images; repeated items are only considered once; all phrases have the same importance; voluntary disclosure is coded; and it is coded when the concept is implicit and explicit.

Finally, we must indicate that the trustworthiness of the content analysis has always been important, and understand that that consistency of the results in this regard is independent of time, investigator, and data collection used Mertens, 1998; Parent \& Deephouse, 2007; Poortman \& Schildkamp, 2012; Street \& Ward, 2012; Wang \& Bella, 2013; Smiraglia, 2014). To check the trustworthiness and credibility of this analysis, a sample of voluntary reports was selected and coded by a highly qualified expert(with an agreement value result of $82.7 \%$ ), and by an expert in this type of coding (with an agreement value of $83.2 \%$ ). Both figures are above the minimum threshold of $70 \%$ required so that they can be accepted.

\subsection{The intangible disclosure index}

We are aware of the importance of the creation of an index in a research (Bravo et al., 2009) because this decision predetermines all the other results obtained by the study. To resolve such prejudices, we decided to construct an index mainly used with intangible assets, as can be observed in Table \#1. As in the previous case, a matrix has been constructed that picks up the presence or absence with a dichotomous approach, with a value of 1 or 0 , respectively, with the 101 indicators found within the voluntary information provided by the companies. On the other hand, and even when there is an important debate between advocates and opponents of the weighted index. Our study uses an unweighted index, and all the items have the same value in order to avoid subjectivity in the weighting process (Ragini, 2012). As mentioned in section 2, the great majority of paper in the field of intangible indexes supports this methodological decision.

Considering all of this, in the first category, intellectual capital concept, the 12 terms initially proposed, transcribed as a maximum score of 240 for this index $-12 * 2 * 7+12 * 1 * 6-$. If we compare the 51 references found in this block that was found in published information of the studied banks, this ratio would allow us to find the desired index. In this way, the Intellectual Capital Concept Index was defined which measures the importance of the intellectual capital concept for each bank, calculated as indicated in the following expression: 


$$
\text { Intellectual Capital Concept Index }=\frac{\sum \text { Points by categorie }}{\text { Maximum Possible Points }} \times 100
$$

Similarly, the Human Capital Index was determined, in which the 25 terms initially proposed, transcribed as $25 * 7 * 2+25 * 6 * 1$, representing a maximum score for this index of 500 points. The results obtained by all them are 142 references, which by comparing that with the maximum score allow us to obtain the index value we proposed. With this index, we can measure the importance of human capital for the sample in a universal manner, as observed in the following expression:

$$
\text { Human Capital Index }=\frac{\sum \text { Points by categorie }}{\text { Maximum Possible Points }} \times 100
$$

For the structural capital category, the Structural Capital Index was calculated, where the importance of this category is analyzed for each of the banks that make up our study. As for the previous categories, we selected 32 terms that transcribe into $32 * 7 * 2+32 * 6 * 1$, which represents a maximum score of 640 mentions. If we compare this with the high score of 126 mentions, we will obtain the value of the index value sought, whose expression is the following:

$$
\text { Structural Capital Index }=\frac{\sum \text { Points by categorie }}{\text { Maximum Possible Points }} \times 100
$$

Likewise, the Relational Capital Index was proposed to measure the importance of relational capital in each of the studied banks, where the selected terms were initially 14 . The highest score obtained was 280 , as it can be determined by $14 * 7 * 20+14 * 6 * 1$. Therefore, to obtain the desired index we compared it with a ratio of 81 mentions obtained by the high score, as observed in the following expression:

$$
\text { Relational Capital Index }=\frac{\sum \text { Points by categorie }}{\text { Maximum Possible Points }} \times 100
$$

Lastly, to measure in a unique manner the importance of the information usefulness category in the sample that was the subject of the study, we used the same procedure for the Information Usefulness Index, in which we considered 18 terms, with a high score of 360 translated into $18 * 7 * 2+18 * 6 * 1$ and 169 mentions. In this way, the ratio comparing the number of mentions obtained with the highest score will give us the result of the proposed index. The expression is as follows:

$$
\text { Information Usefulness Index }=\frac{\sum \text { Points by categorie }}{\text { Maximum Possible Points }} \times 100
$$

However, to measure the importance of all the categories in our study, the Aggregated Category Index was calculated for all the banks. In this case, we selected the 5 previously mentioned categories, along with their terms, and calculated the ratio by comparing 569 mentions against the resulting high score of 2020. The result will be the sought index. The expression used to calculate it is as follows:

$$
\text { Aggregate Index }=\frac{\sum \text { Points by categorie }}{\text { Maximum Possible Points }} \times 100
$$

In order to assess the implications of the indexes proposed for the financial institutions listed on the IBEX 35, we must mention that the maximum score that can be obtained by the index is $100 \%$, taking into account that all the terms that make up the categories appear in all of the analyzed financial reports.

\section{Results}

The construction of the intangible disclosure index allows information to be added and offers a condensed view of the amount of disclosure in each of the proposed categories, as well as a global view for these practices on the part of financial institutions. See Table 3 with the partial and aggregated indexes obtained by our paper. 


\begin{tabular}{|c|c|c|c|c|c|c|}
\hline & 2010 & 2011 & 2012 & $\begin{array}{l}\text { Period } \\
\text { variation } \\
(2012-2010)\end{array}$ & $\begin{array}{l}\text { Period } \\
\text { variation 2011- } \\
2010\end{array}$ & 2010 \\
\hline ICI (Intellectual Capital Concept Index) & $19.44 \%$ & $21.43 \%$ & $20.24 \%$ & $0.80 \%$ & $1.99 \%$ & $-1.19 \%$ \\
\hline HCI(Human Capital Index) & $26 \%$ & $27.43 \%$ & $29.14 \%$ & $3.14 \%$ & $1.43 \%$ & $1.71 \%$ \\
\hline SCI (Structural Capital Index) & $18.75 \%$ & $17.86 \%$ & $19.64 \%$ & $0.89 \%$ & $-0.89 \%$ & $1.78 \%$ \\
\hline RCI(Relational Capital Index) & $28.57 \%$ & $25.51 \%$ & $28.57 \%$ & $0 \%$ & $-3.06 \%$ & $3.06 \%$ \\
\hline IUI (Information Usefulness Index) & $47.22 \%$ & $44.44 \%$ & $43.65 \%$ & $-3.57 \%$ & $-2.78 \%$ & $-0.79 \%$ \\
\hline Aggregated Index & $27.06 \%$ & $26.44 \%$ & $27.43 \%$ & $0.37 \%$ & $-0.62 \%$ & $0.99 \%$ \\
\hline
\end{tabular}

Table 3. Partials and aggregated indexes

The results obtained by our study situate the aggregated index of intangible disclosure at a level close to $27 \%$ during the period analyzed. This implies that we can summarize with this figure the disclosure policy used by the banks studied. If we observe the evolution of the aggregated index, we find that the variations are not significant, not even reaching one percent, so for 2010-2012 the final increase was insignificant, at $0.37 \%$. Therefore, it is deduced that there is no mayor change in the intangible disclosure strategy.

If the analysis is conducted with each partial index, it can be observed that the information usefulness index reaches the greatest value of all the years analysed with a value over $40 \%$ in all cases. This means that it is the most disclosed category by financial institutions, even though it was the only category that reduced its presence during 2010 to 2012. In second place is the relational capital index with a percent close to 30\%, though in 2011 this is considerably lower at $25.51 \%$ and its final evolution was zero, that is, it has the same value as when it started in 2010. The human capital index also has a significant position with values close to $30 \%$ and an increase of $3.14 \%$ during the analyzed period. Intellectual capital concept and structural capital indexes are in last positions, with levels close to $20 \%$ and a similar increase of 0.89 and $0.80 \%$, respectively, during the three years studied.

In Table 3, we have tried to establish an evolutionary analysis of the practice of intangible disclosure in the past and form an opinion on its trend. It can be observed that most of the indexes have increased thanks to the number of mentions in analyzed reports, and it is noted that information usefulness was the most disclosed category during the three years. In this regard, during the first year studied, 2010, the information usefulness index is followed by relational capital, human capital, and structural capital in order of importance and, somewhat more distanced is intellectual concept capital. In 2011, although information usefulness remains in first place in disclosure, the order of the indexes is different. It is followed by human capital, relational capital, intellectual concept capital, and in last place, structural capital. Lastly, in 2012, while the trend is an increase in most of the indexes, a slight decrease in information usefulness and intellectual concept capital was noted.

\section{Discussion}

Our study confirms first that the level of the disclosure of intangible assets is not high for Spanish financial institutions, which is in line with previous findings. Likewise, Ferreira et al. (2017) found a global index in the annual report of $36.93 \%$ and of $28.60 \%$ in corporative websites. Likewise, Munthopa (2013) found an intellectual capital disclosure index of $32 \%$, corresponding to $40 \%$ for internal capital category, $32 \%$ for external capital, and the rest $28 \%$ for human capital. In addition, Rodríguez et al. (2013) calculated a disclosure index for intellectual with a value of 1,037, with minimum and maximum values that fluctuated between 0 and 2. For Haji and Mubaraq (2012), the disclosure index of intellectual capital reached a level of $35.45 \%$ in $2006,37.16 \%$ in $2007,37.50 \%$ in 2008 and $41.02 \%$ in 2009.

We were far from the numbers presented by authors such as Herrera and Macagnan (2012) for disclosure in Spain, $60.66 \%$ for 158 items, even though there is no temporal coincidence between both papers. In addition, in a previous study, Herrera and Macagnan (2016) built a disclosure index for structural capital for Spanish banks that has high levels that fluctuate between $73.21 \%$ and 58.37\% (2006 and 2011, respectively). We understand that the time horizon studied explains these differences, as it was pointed out. Spanish banks spearheaded the 
management of intangible assets (Castilla \& Ruiz, 2014) and now the levels of these kinds of disclosures are relatively low, which is in line with most of the findings of the studies for these kinds of companies.

Second, the disclosure of intangibles by Spanish banks is heterogeneous according to the values achieved by the partial indexes created in this paper that show more revealed categories and others of less interest. These will be examined in detail by collected terms for the 5 analyzed categories: intellectual capital concept, human capital, structural capital, relational capital, and useful information, showing a stable participation. It stands out as the highest index relative to useful information of intangible assets, in other words, it refers to the benefits that are, in theory, associated with the intangible equity.

Following on from the useful information index, we find the indexes corresponding to the three classic categories of the study of intellectual capital: human, relational, and structural capital that in our study occupy second, third and last place respectively. The importance of external intangible assets, the relational block, is also relevant and occupies first place in the Chander and Mehra (2011) study. According to Ferreira et al. (2017), the relevance of human capital is confirmed in $\mathrm{f}$ annual reports, because corporate websites confirm the prevalence of relational capital. Finally, the structural capital occupies first place in order of importance in the papers by Cerbioni and Parbonetti (2007), Munthopa (2013) and Sharma and Kaur (2016). We should mention that the difference between sectors and industries analysed by the previous papers has a direct influence on the explanation of the results found in the case of the banks studied, even more with the specific elements of these organizations.

Thirdly, our results support those studies that show an increasing, albeit very small, trend for these types of disclosures Williams, 2001, Bergamini \& Zambon, 2005, Bukh et al., 2005 or Ragini, 2012, among others. If we a nalyze our results, the global index variation is $0.37 \%$ between $2010-2012$, which essentially shows the stability in the disclosure of intangible assets, though, there is more variation for the useful information index that fell $3.57 \%$ and for the human capital index that increased $3.14 \%$. The rest of the indexes are lower than $1 \%$ and even 0 , with no variation, in the relational human capital index.

Therefore, both the level and trends of intangible disclosure in our study are supported by a necessary caution within the area of research that the content analysis uses. We have reviewed of all voluntarily disclosed reports, at the expense of papers that are mostly based on annual reports (Castilla \& Ruiz, 2017) and, recently, in these and on corporate websites (Ferreira et al., 2017). Specifically, we consider that increasing the number and kind of analyzed reports can contribute to increasing both the credibility and reliability of the content analysis required to create any kind of index. On the contrary, the results could not be as conclusive because no other voluntary reports are included in the analysis.

\section{Conclusions, limitations and future lines of research}

Even though financial institutions have incorporated the disclosure of intangible assets in recent years, its relevance and lack of knowledge justify any approach to them. Our results weigh the intangible disclosure polices through an aggregated index at $26.98 \%$ for the study period, which evidences that the level is not relatively high, as well as a global variation close to zero between 2010 and 2012, specifically an increase of $0.37 \%$. Furthermore, within the partial indexes, the predominant index that obtained the highest score was useful information capital, followed by structural capital and intellectual concept capital. The most disclosed category includes all the registry units associated with the role of the advantages of these kinds for disclosures and has a key role within the results found, a significant finding not covered to date and that is linked to the need for greater research of the relationship between voluntary disclosure and usefulness.

With all this said, it can be concluded that it is expected that the banks studied would have been committed to disclosing more information about their intangible assets, in other words, that the aggregated index would have been higher. We mean taking advantage of these occasions to, despite greater regulation, "improve their ability to manage their intellectual capital and find sustainable competitive advantages" (Ferreira et al. 2017, pp. 493). Likewise, no significant changes can be found in the evolution of different indexes, for neither aggregated or partial indexes, with which the stability of these policies can be confirmed in the case of the banks analyzed. 
While a significant aggregated index was not found against the expectations created by the role of financial reporting to increase transparency and because of the complex situation, in which this is specifically measured, we insist on the idea of the use of intangible assets disclosure. This is fundamental means to disclose that, along with fiscal capital, financial institutions have a large intangible equity, allowing them to remain competitive.

Finally, we must indicate that this study is subject to limitations, which we understand constitute opportunities for future studies. We think that the period studied could be increased, specifically for the period 1999-2017, thereby revealing a complete view of how the disclosure of intangible assets has evolved over time from when Intellectual Capital Reports were disclosed as specific reports to the present day, where these are no longer prepared. In addition, we find interesting to analyze not only the quantity but also the quality of these disclosures by assessing the different interest groups in line with papers such as Kanakriyah (2016). In fact, a limitation of our study, and by extension all those mainly based on indexes, is the fact that we looked at the study of quantity and not the quality of voluntary disclosures (Teodori \& Veneziani, 2010). In the future, it will be a necessary line of research in this field. Another important and appropriate aspect for future research in this topic would be the use of a qualitative methodology in order to get closer to the day-to-day reality of these entities and ask them about the reasons behind the position found.

\section{Declaration of Conflicting Interests}

The authors declared no potential conflicts of interest with respect to the research, authorship, and/or publication of this article.

\section{Funding}

The authors received no financial support for the research, authorship, and/or publication of this article.

\section{References}

Abdifatah, A.H., \& Mubaraq, S. (2012). The trends of intellectual capital disclosures: Evidences from the Nigerian banking sector. Journal of Human Resource Costing and Accounting, 16(3), 184-209. https://doi.org/10.1108/14013381211286360

Bamber, M., \& McMeeking, K. (2010). An examination of voluntary financial instruments disclosures in excess of mandatory requirements by UK FTSE 100 non-financial firms. Journal of Applied Accounting Research,11(2), 133-153. https://doi.org/10.1108/09675421011069504

Beaulieu, P.R., Williams, S.M., \& Wright, M.E. (2002). Intellectual Capital Disclosures in Swedish annual reports. In N.E., Bontis (Ed.), World Congress on Intellectual Capital Readings (pp. 135-156). Hamilton, ButterworthHeinemann. https://doi.org/10.1016/B978-0-7506-7475-1.50012-9

Bellora, L., \& Guenther, T.W. (2013). Drivers of innovation capital disclosure in intellectual capital statement: Evidence from Europe. The British Accounting Review, 45, 225-270. https://doi.org/10.1016/j.bar.2013.06.002

Bergamini, I., \& Zambon, S. (2005). A scoring methodology for ranking company disclosure in intangibles. EU Prism Research Project. WP4 Accounting, Auditing and Financial Analysis in the New Economy. Retrieved September, 2019 from: www.euintangibles.net/library/localfiles/WP4/4.2. Bergamini\&Zambon2002.pdf

Blaise, S., Carson, K., \& Phillips, P. (2008). Intellectual capital disclosure by traditional US companies: A longitudinal assessment. Journal of Accounting and Organizational Change, 4(1), 67-80. https://doi.org/10.1108/18325910810855798

Bozzolan, S., Favotto, F., \& Ricceri, F. (2003). Italian annual intellectual capital disclosure: An empirical analysis. Journal of Intellectual Capital, 4(4), 543-558. https:// doi.org/10.1108/14691930310504554

Brand Finance (2017). Global intangible finance tracker (gift) 2017. An annual review of the world's intangible value. Brand Finance Institute. Retrieved September. 2019 from: http://brandfinance.com/images/upload/gift report 2017 ce version high res version.pdf 
Bravo, F., Abad, M.C., \& Trombetta, M. (2009). Disclosure indices design: does it make a difference? Spanish Accounting Review, 12(2),253-277. https://doi.org/10.1016/S1138-4891(09)70008-1

Bukh, P.N., Nielsen, C., Gormsen, P., \& Mouritsen, J. (2005). Disclosure of information on intellectual capital in Danish IPO prospectuses. Accounting, Auditing and Accountability Journal, 18(6), 713-732. https://doi.org/10.1108/09513570510627685

Cañibano, L., García-Meca, E., García-Osma, B., \& Gisbert, A. (2009). Los activos intangibles en la nueva regulación contable. Cuadernos de Gestión del Conocimiento Empresarial, 10 [In Spanish].

Castilla, F., \& Ruiz, M.C. (2014). Una revisión histórico-descriptiva de las empresas pioneras en el tratamiento de intangibles. Intangible Capital, 10(1), 125-154 [In Spanish].

Castilla, F., \& Ruiz, M.C. (2017). La divulgación de intangibles en entidades financieras: Un análisis de contenido. Revista Españolade Financiación y Contabilidad, 47(1), 81-123 [In Spanish]. https://doi.org/10.1080/02102412.2017.1346912

Centro de Investigación para la Sociedad del Conocimiento (IADE-CIC) (2003). Modelo Intellectus: Medición y gestión del capital intelectual. Documento Intellectus, 5 [In Spanish].

Cerbioni, F., \& Parbonetti, A. (2007). Exploring the Effects of Corporate Governance on Intellectual Capital Disclosure: An Analysis of European Biotechnology Companies. European Accounting Review, 16(4),791-826. https://doi.org/10.1080/09638180701707011

Chander, S., \& Mehra, V. (2011). A study on intangible assets disclosure: can evidence from Indian companies. Intangible Capital, 7(1), 1-30. https://doi.org/10.3926/ic.2011.v7n1.p1-30

Chen, K.C., Danbolt, J., \& Holland, J. (2014). Rethinking bank business models: the role of intangibles. Accounting, Auditing \& Accountability Journal, 27(3), 563-589. https://doi.org/10.1108/AAAJ-11-2012-1153

Chen, K.C., \& Pan, C.Y. (2011). An Empirical Study of Credit Risk Efficiency of Banking Industry in Taiwan. Web Journal of Chinese Management Review, 15(1), 1-16. https://doi.org/10.1504/IJSTM.2011.041980

De Silva, T., Stratford, M., \& Clark, M. (2014). Intellectual capital reporting: A longitudinal study of New Zealand companies. Journal of Intellectual Capital,15(1),157-172. https://doi.org/10.1108/JIC-03-2013-0034

Devalle, A., Rizzato, F., \& Busso, D. (2016). Disclosure indexes and compliance with mandatory disclosure- The case of intangible assets in the Italian Market. Advances in Accounting, 35, 8-25.

https://doi.org/10.1016/j.adiac.2016.04.003

Dumay, J. (2013). The third stage of IC: Towards a new IC future and beyond. Journal of Intellectual Capital, 14(1), 5-9. https://doi.org/10.1108/14691931311288986

Ferreira, M.R., Ribeiro, M.L., Gomes-Rodrígues, A.M., \& Muñoz, M.P. (2017). Competitiveness and disclosure of intellectual capital: An empirical research in Portuguese Banks. Journal of Intellectual Capital, 18(3), 486-505. https://doi.org/10.1108/JIC-11-2016-0112

Fier, S., \& Williams, S.M. (2005). Firm ownership structure and intellectual capital disclosures. Journal of Accounting Research, 19(1), 1-18. https://doi.org/10.1080/10291954.2005.11435116

Gandía, J.L. (2002). La divulgación de información sobre intangibles en Internet: Evidencia internacional. Revista Española de Financiación y Contabilidad, XXXI(113),767-802 [In Spanish]. https://doi.org/10.1080/02102412.2002.10779461

García-Meca, E., \& Martínez, I. (2005). Assessing the quality of disclosure on intangibles in the Spanish capital market. European Business Review, 17(4), 305-313. https://doi.org/10.1108/09555340510607352

García-Meca, E., Parra, I. Larrán, M., \& Martínez, I. (2005). The exploratory factors of intellectual capital disclosure to financial analyst. European Accounting Review, 14(1), 63-94.

https://doi.org/10.1080/0963818042000279713 
Gorgan, C., \& Gorgan, V. (2014). Study on disclosure level of companies listed on the Bucharest stock exchange in accordance with international financial reporting standards: The case of intangible assets. Anales de la "Constantin Brâncusi".University of Targu Jiu, Economis Series, 2, 104-115.

Haji, A.A., \& Mubaraq, S. (2012). The trends of intellectual capital disclosures: Evidence from the Nigerian banking sector. Journal of Human Resource Costing \& Accounting,16(3), 184-209. https://doi.org/10.1108/14013381211286360

Herrera-Rodríguez, E.E., \& Macagnan, C.B. (2012). Nivel de transparencia de recursos intangibles de los bancos: Panamá, Brasily España. In Tourism and Management Studies International Conference, University of Algarve 2012, 3.ISBN 978-989-8472-25-0. Universidad del Algarve, Portugal [In Spanish].

Herrera-Rodríguez, E.E., \& Macagnan, C.B. (2016). Revelación de informaciones sobre capital estructural organizativo de los bancos de Brasil y España. Contaduría y Administración, 61(1), 4-25 [In Spanish]. https://doi.org/10.1016/j.cya.2015.09.007

Holsti, O.R. (1969). Content analysis for the social sciences and bumanities. Mass: Massachusetts: Longman Higher Education, Reading.

International Accounting Standards Board (IASB) (2004). International Financial Reporting Standard (IFRS) No. 38 on Intangible Assets. Retrieved September, 2019 from: http://www.icac.meh.es/Normativa/Documentoscontabilidad.aspx

Kanakriyah, R. (2016). Voluntary disclosure and its effects on the quality of accounting information according to Users' Perspective in Jordan. American Journal of Business, Economics and Management, 4(6),134-146.

Kang, H. (2006). Reporting intangible assets. Voluntary disclosure practices of the top emerging market companies (Ph. D. Dissertation). The University of New South Wales, Australia.

Kang, H.H., \& Gray, S.J. (2011). Reporting intangible assets: voluntary disclosure practices of top emerging market companies. The International Journal of Accounting,46, 402-423. https://doi.org/10.1016/j.intacc.2011.09.007

Kohlbeck, M. (2004). Investor valuation sand measuring Banks Intangible Assets. Accounting, Auditing \& Finance Journal,19(1), 29-60. https://doi.org/10.1177/0148558X0401900104

Kumar, G. (2013). Voluntary disclosures of intangible information by U.S.-listed Asian companies. Journal of International Accounting, Auditing and Taxation, 22, 109-118. https://doi.org/10.1016/j.intaccaudtax.2013.07.002

Li, J, Pike, R., \& Haniffa, R. (2008). Intellectual Capital disclosure and corporate governance structure in UK firms. Accounting and Business Research, 38(2), 137-159. https://doi.org/10.1080/00014788.2008.9663326

Lim, S.J., White, G., Lee, A., \& Yuningsih, Y. (2017). A longitudinal study of voluntary disclosure quality in the annual reports of innovative firms. Accounting Research Journal, 30(1), 89-106. https://doi.org/10.1108/ARJ-082013-0056

Lopes, I.T. (2010). Towards a complementary reporting approach. Measuring Business Excellence, 14(4), 24-34. https://doi.org/10.1108/13683041011093730

Macagnan, C.B. (2007). Condicionantes e implicación de revelar activos intangibles (Tesis Doctoral). Universidad Autónoma de Barcelona, Barcelona [In Spanish].

Mertens, D.M. (1998). Research methods in education and psychology: Integrating diversity with quantitative \& qualitative approaches. USA: Sage Publications, Thousand Oaks.

Munthopa, L. (2013). Visualization of Intellectual Capital disclosures in annual reports of commercial banks of Malawi. Interdisciplinary Journal of Contemporary Research Business, 5(3), 155-169 [In Spanish].

Oliveira, L., Rodríguez-Lima, L., \& Craig, R. (2006). Firm-specific determinants of intangibles reporting: Evidence from the Portuguese stock market. Journal of Human Resource Costing \& Accounting, 10(1), 11-33. https://doi.org/10.1108/14013380610672657 
Oliveira, L., Rodríguez-Lima, L., \& Craig, R. (2010). Intellectual capital reporting in sustainability reports. Journal of Intellectual Capital, 11(4), 575-594. https://doi.org/10.1108/14691931011085696

Parent, M.M., \& Deephouse, D.L. (2007). A case study of stakeholder's identification and prioritization by managers. Journal of Business Ethics, 75(1), 1-23. https://doi.org/10.1007/s10551-007-9533-y

Poortman, C.L., \& Schildkamp, K. (2012). Alternative quality standards in qualitative research?- Quality \& Quantity, 46(6), 1727-1751. https://doi.org/10.1007/s11135-011-9555-5

Ragini (2012). Corporate Disclosure of Intangibles: a comparative study of practices among Indian, Japanese Companies, and US. Vikalpa, 37(3), 51-72. https://doi.org/10.1177/0256090920120305

Rodríguez, L., Gallego, I., \& García, I.M. (2010). Determinantes de la divulgación voluntaria de información estratégica en internet: Un estudio de las empresas españolas cotizadas. Revista Europea de Dirección y Economía de la Empresa, 19(1), 9-26 [In Spanish].

Rodríguez, P., Fuentes, F.., \& Sánchez, S. (2013). Revelación de información sobre clientes, comunidad, empleados y medio ambiente en las entidades financieras españolas a través de las memorias de responsabilidad social corporativa (2007-2010). Investigaciones Europeas de Dirección y Economía de la Empresa, 19(3), 180-187 [n Spanish]. https://doi.org/10.1016/j.iedee.2012.12.002

Ruiz, M.C., \& Castilla, F. (2016). El papel de la información financiera en la evolución reciente del sector bancario español. Revista de Estudios Empresariales, Segunda Época, 2, 55-74 [In Spanish].

Shakina, E., \& Molodchik, M. (2014). Intangible-driven value creation: Supporting and obstructing factors. Measuring Business Excellence, 18(3), 87-100. https://doi.org/10.1108/MBE-12-2013-0063

Sharma, K., \& Kaur, M. (2016). Web Based Disclosure Practices of Intangible Assets of Selected Indian Companies-An Empirical Study. Imperial Journal of Interdisciplinary Research (IJIR), 2(3), 521-528.

Smiraglia, R.P. (2014). The elements of knowledge organization. New York: Springer. https://doi.org/10.1007/978-3-319$09357-4$

Street, C.T., \& Ward, K.W. (2012). Improving validity and reliability in longitudinal case studies timeline. European Journal of Information System, 21(2), 160-175. https://doi.org/10.1057/ejis.2011.53

Tejedo, F. (2011). Información divulgada de capital intelectual en el marco de la responsabilidad social empresarial y del gobierno corporativo. Evolución y factores determinantes (Tesis Doctoral). Universidad de Castilla La Mancha, Albacete [In Spanish].

Tejedo, F. (2014). Información del conocimiento organizaciones a través de los informes publicados en las páginas web de las empresas. Revista Española de Documentación Cientifica, 37(1), 1-13. https://doi.org/10.3989/redc.2014.1.1068

Tejedo, F. (2016). Información de los recursos intangibles ocultos: ¿Memorias de sostenibilidad o informe anual? European Research on Management and Business Economics, 22, 101-109 [In Spanish]. https://doi.org/10.1016/j.iedee.2015.06.001

Teodori, C., \& Veneziani, M. (2010). Intangible assets in annual reports: a disclosure index. Retrieved September, 2019 from: http://www.unibs.it/sites/default/files/ricerca/allegati/Paper99.pdf [In Spanish].

Tracy-Anne, S., Stratford, M. \& Clark, M. (2014). Intellectual Capital reporting: a longitudinal study of New Zealand Companies. Journal of Intellectual Capital, 15(1), 157-172. https://doi.org/10.1108/JIC-03-2013-0034

Vandemaele, S.N., Vergauwen, P.G., \& Smith, A.J. (2005). Intellectual capital disclosure in The Netherlands, Sweden and the UK: A longitudinal and corporative study. Journal of Intellectual Capital, 6(3), 417-426. https://doi.org/10.1108/14691930510611148

Wang, T.L., \& Bella-Lien, Y.H. (2013). The power of using video data. Quality \& Quantity, 47(5), 2933-2941. https://doi.org/10.1007/s11135-012-9717-0 
Williams, S.M. (2001). Is intellectual capital performance and disclosure practices related? Journal of Intellectual Capital, 2(3), 192-203. https://doi.org/10.1108/14691930110399932

Zeghal, D., \& Maaloul, A. (2011). The accounting treatment of intangibles - A critical review of the literature. Accounting Forum, 35(4), 262-274. https://doi.org/10.1016/j.accfor.2011.04.003

Intangible Capital, 2019 (www.intangiblecapital.org)

\section{(c) (i) (5)}

Article's contents are provided on an Attribution-Non Commercial 4.0 Creative commons International License. Readers are allowed to copy, distribute and communicate article's contents, provided the author's and Intangible Capital's names are included. It must not be used for commercial purposes. To see the complete license contents, please visit https://creativecommons.org/licenses/by-nc/4.0/. 